DOI https://doi.org/10.36059/978-966-397-169-8/1-23

\title{
EXPERIENCE OF CREATING A PROSOPOGRAPHIC PORTRAIT OF PROFESSOR BORIS ALEKSEEVICH SHUSTOV (1880-1945)
}

\section{Yuliia Dobrolyubska}

\section{INTRODUCTION}

At the beginning of the 21st century, the personification of history, which sets the basis of events and phenomena of the past person with its extraordinary intellectual and organizational skills, civic position, endowments and concrete Actions. The strong interest of the famous person, observed in recent decades, encourages the researcher not only to write her biography, to list facts and events of life and activity, but also to deepen her personal essence, which often explains the causes and Consequences of biographic facts. That is, the personification of the past, as an actual task of modern historical studios, involves the reproduction of the gallery of famous figures not in the traditional coverage of the usual biography, but in a deeper study of personal and individual content of a particular person or groups of people linked by generic, professional or other relationships.

This interest in a person in history requires from modern researchers not only writing biographies, enumeration and refinement of individual facts, dates, but also in-depth study of human personality, throughout the versatility of her socio-psychological and individual Rice. In the context of mass desecration of archival documents and active introduction to the scientific circulation of new sources of historians and source studies, it becomes available valuable material of impregnating nature. It allows you to create live portraits of famous people, reproduce their images in a combination of positive and negative sides biography, not enclosed in a static framework of dry biography.

The purpose of this article is to create an impregnating portrait of arborist Boris Alekseevich Shustov because of the most characteristic aspects of his biography. 


\section{The personal destiny of the arborist in the context of social change}

The description of the history of the persecution of foresters of Ukraine in 1930 (case of the All-Ukrainian Forest Management or VUPL) was reflected in the books of P. G. Vakuluk "The Case of VUPL", "Rehabilitated by History", "Essays on Forest History Ukraine", "Foresters are victims of the totalitarian system"3, "Foresters are the chief forest manager", "Reforestation and deforestation in Ukraine" . Shustov's accusations of counter-revolutionary pestilence are remembered in the book "The First Figures of Ukrainian Forestry" by O. I. Furdychko and V. D. Bondarenko ${ }^{6}$. The materials of the investigation on the case of the VUPL, including the accusations of Professor B. A. Shustov, are briefly described in the book by V. E. Boreiko "White Spots of Nature Conservation"7.

Interesting material for understanding the relationship of the totalitarian regime with the Ukrainian intelligentsia is provided by V. G. Kasyanov's research "Ukrainian Intelligence of the 1920s 1930s: A Social Portrait and a Historical Destiny"”.

Overall, the analysis of the historiography of the forestry shows numerous gaps in the coverage of the period in the history of the industry. There are no studies on the activity in the specified field by Professor B. A. Shustov.

${ }^{1}$ Vakuljuk P. G. (1994) Sprava VUPLu [The case of VUPL]. Kiev: [b. v.].

${ }^{2}$ Vakuljuk P. G. (1998) Reabilitovani istorijeju [Rehabilitated by History]. Kiev: [b. v.].

${ }^{3}$ Vakuljuk P. G. (2004) Lisivnyky - zhertvy totalitarnoji systemy [Foresters are victims of the totalitarian system]. Kiev: Ukrcentrkadrlis.

${ }^{4}$ Vakuljuk P. G. (2005) Lisnychyj - gholovnyj ghospodar lisu [Foresters are the chief forest manager]. Kiev: Ukrcentrokadrlis.

5 Vakuljuk P. G. (2006) Lisovidnovlennja ta lisorozvedennja v Ukrajini [Reforestation and deforestation in Ukraine]. Kharkov: Prapor.

6 Furdychko O. I., Bondarenko V. D. (2000) Pershopostati ukrajinsjkogho lisivnyctva. Narysy do lisovoji istoriji [The First Figures of Ukrainian Forestry. Essays on forest history]. Lviv: Bibljos.

7 Boreyko V.E. (2003) Belye pyatna prirodookhrany [White spots of Nature Conservation]. Kiev: Logos.

${ }^{8}$ Kasjjanov V. G. (1992) Ukrajinsjka intelighencija 1920-kh - 1930-kh rokiv: socialjnyj portret ta istorychna dolja [Ukrainian Intelligence of the 1920s - 1930s: A Social Portrait and a Historical Destiny]. K.: Ghlobus. 
Mostly unpublished sources were used to write this study, which formed the basis of our work. By their specific features, these sources can be divided into two groups: unpublished materials kept in state institutions and unpublished materials of the family archive of the author, the greatgranddaughter of Boris Shustov. From the documents of the family archive, which were miraculously preserved by the grandmother of the author of this work, Marina Borisovna Shustova, miraculously against the war, evacuation and many relocations of the family, were used: diploma of the New Alexandrian Imperial Forest Institute 1907, passport 1909, passport 1919-1937, employment record 1937-1945, autobiography 1942, order on the assignment of the academic title of professor in 1942, order for the transfer of the family to the village of Lubyan Tatar ASSR 1942, autobiography 1944, death certificate B. A. Shustov 1945.

A valuable source of information on the history of Ukrainian forestry and forestry during the first post-revolutionary decades, as well as the state of forestry in the late 1920s. became the documents of the Branch State Archives of the Security Service of Ukraine, which holds the three-volume case No. 68461 on allegations of counterrevolutionary activity by a group of leading Ukrainian forestry experts (the case of VUPL). Among the significant texts of the testimony of the investigating professors, numerous details of biographies of forestry workers, including Boris Shustov, are also revealed ${ }^{9}$.

Boris Shustov was born on October 22 (9), 1880 in the town of Sedniv, Chernihiv province, to the family of village teacher Alexei Shustov and his wife, Agathia Petrovna. Consistory in the metric book of registration of act records of the birth of St. George Church in the town of Sedniv of Chernihiv county of Chernihiv province for 1880 is act record No. $34^{10}$.

${ }^{9}$ Delo VUPL. Otraslevoy gosudarstvennyy arkhiv Sluzhby bezopasnosti Ukrainy (OGA SB Ukrainy) [Case of VUPL. Branch State Archive of the Security Service of Ukraine (BSA SS of Ukraine)]. D. 68461. vol. 1-3. (unpublished); Protokol sudebnogo zasedaniya ot $14.06 .30 \mathrm{~g}$. [The record of the court hearing of June 14, 30]. OGA SB Ukrainy [BSA SS of Ukraine]. D. 68461. vol. 2. p. 630. (unpublished)

${ }^{10}$ Arkhivnyj fond Chernighivsjkoji dukhovnoji konsystoriji f. 679, op. 10, spr. 317, ark. $440 z v$. [Archive Fund of the Chernigiv Spiritual Consistory. F. 679. Op. 10. Sp. 317, arch. $440 \mathrm{zv}$ ]. (unpublished) 
In 1902 he graduated from the Uman School of Agriculture and Horticulture, and in 1907 - St. Petersburg (Novo-Alexandria) Forest Institute with the title of scholar of the 1st class. As the best alumnus B. Shustov was enrolled for 2 years with a scholarship of the highest salary from Professor M. M. Orlov. In 1908-1916 he was an assistant at the Department of Forest Management and Forest Taxation, managed by M. M. Orlov. With the outbreak of World War I, by the order of the military command in 1914, the institute was evacuated to Kharkov. Already in November 1914, classes began in Kharkov, which were held both in the auditoriums of the University, and of the Technological and Veterinary Institutes. In 1917, the Academic Council of the New Alexandria Institute of Agriculture and Forestry, on the recommendation of M. M. Orlov, elected B. A. Shustov Professor of the Department of Forest Taxation. Released from military service, Shustov left the Forest Institute in Petrograd and moved to Kharkov.

In 1919, during the reign of the Denikinists in Kharkov, in search of additional earnings, B. A. Shustov, together with his colleagues, Alexander Kolesnikov, Ivan Kovalenko and Boris Padalko, organized a private office on Rybnaya Street in Ribnaya Street. Bureau has undertaken work on forestry plans and forest evaluation for the needs of their owners and peasant communities ${ }^{11}$.

On March 21, 1921, the Novo-Alexandria Institute of Agriculture and Forestry was named Kharkov Agricultural Institute. The Institute was classified as a particularly important institution, which provided for its urgent full provision of everything necessary. In the same year, the Institute started new structural units - faculties: agronomic, amelioration and forestry. At the general meeting of faculty and students of the Faculty of Forestry, the first dean elected the most experienced professor, Alexander Marchenko. After his transition to the post of director of the All-Ukrainian Forest Management (VUPL), Professor Boris Shustov was elected the second dean in the fall of 1922.

11 Triputina N. P. (2011) Professor A. I. Kolesnikov: stranitsy zhizni i deyatel'nosti [Professor A. I. Kolesnikov: pages of life and activity]. Kharkov: KhNAGKh. 
Since 1922 new departments have been created at the Faculty of Forestry: Dendrology (Head - Professor V. M. Andriyev), Forest Cultures (Head - Professors A. P. Tolsky, I. O. Yakhontov), Forest Taxation (Head - Professor B. A. Shustov), forest reclamation (heads professors M. M. Stepanov, V. Y. Gursky), state forestry and forestry statistics (head A. Kolesnikov). The Department of Forestry has been headed by the renowned professor G. M. Vysotsky since 1925. In 1927, they also organized a research department of forestry in four sections: forestry, dendrology, forest crops and forest reclamation. Professor G. M. Vysotsky was also the head of this department, and the sections were headed by Professors V. M. Andriyev, I. O. Yakhontov, V. Y. Gursky. In December 1929, the Ukrainian Research Institute of Forestry and Agroforestry was organized on the basis of the Research Department of Forestry.

Until 1930, B. A. Shustov was Professor and Head of the Department of Forest Taxation of the Kharkov Agricultural Institute, including 3 years (from 1922 to 1925) - Dean of the Faculty of Forestry. He was also the Deputy Chief of the All-Ukrainian Forest Directorate (VUPL).

On January 20, 1930, Professor B..A. Shustov was arrested and convicted of anti-Soviet counter-revolutionary activity.

The materials of the archival investigative case do not contain information about the place of serving the sentences of the convicted persons and the actual term of their imprisonment. Kyiv researcher P. G. Vakuluk found unofficial information that the sentenced persons in the case owed to the great enthusiast of the forestry business to the Chairman of the National People's Commissar V. Y. Chubar ${ }^{12}$. Professor Shustov's autobiography from 1942, which is preserved in the family archive, states: "From the second half of 1930 and the first half of 1931, he served sentences in the general detention facilities of the city of Kharkov while conducting research". But in another autobiography, which according to a handwritten note

${ }^{12}$ Vakuljuk P. G. (2000) Narysy z istoriji lisiv Ukrajiny [Essays on Forest History Ukraine]. Fastiv: Polifast. p. 287. 
on his return to Bryansk can be dated in the autumn of 1944, there is no mention of arrest and court.

Soviet authorities nationalized the forests of Ukraine. To develop strategy and tactics of managing this complex and extremely neglected economy, to prepare highly qualified specialists in this matter, the newly created departments of Kharkov Agricultural Institute were called $^{13}$.

In the spring of 1920, the All-Ukrainian Forest Management (VUPL) was established in Kharkov under the People's Commissariat of Land Affairs of the Ukrainian SSR.

With the strengthening of the totalitarian system in the country, persecution against domestic specialists of the old school increased. In early 1928, Stalin put forward the thesis of further exacerbation and class struggle in the process of building socialism. The Shakhtin case, the Prom-Party process, and mass political repression against employees of Kharkov agricultural universities were inspired ${ }^{14}$. The target of one of the lawsuits to combat "counter-revolutionary pest" was the heads of the All-Ukrainian Forest Management (VUPL). In the autumn of 1929, Ukrainian foresters were one by one behind the bars: Valerian Gursky, Ivan Kovalenko, Boris Padalko, Alexander Marchenko, Boris Shustov.

The so-called "witnesses" - F. Golovchenko, P. Vorobyov, A. Tsirkul, E. Sadovsky, A. Nikitenko, S. Vasilyev - helped a lot.

F. Golovchenko told the Chekists that the "enemies" did not publish in the magazine "Ukrainian Arborist" his articles, which called for a socialist reconstruction of forestry. However, the young "red arborist" Pavel Vorobyov helped the investigators especially with great care. As a student of the Faculty of Forestry of Kharkov Agricultural Institute, he was offended by Professor Shustov when he rejected his project of felling in the Gomolshansky Forest Cottage. And now, taking advantage of the opportunity, he kept billing. As the famous "friend of the French people"

${ }^{13}$ Pyatnitskiy S. S. (1966) Istoricheskiy ocherk fakul'teta lesovodstva [History of the Faculty of Forestry]. 150 let Khar'kovskomu ordena Trudovogo krasnogo znameni sel'skokhozyaystvennomu institutu im. V. V. Dokuchaeva (1816-1966) [150 years of the Kharkov Order of the Red Banner of Labor Agricultural Institute. V. V. Dokuchaev (1816-1966)]. p. 94.

${ }^{14}$ Kasjjanov V. G. (1992) Ukrajinsjka intelighencija. Pp. 92-93. 
Jean-Paul-Marat, until the revolution, unknown to any physician and unsuccessful chemist, overwhelmed the head of the French Academy of Lavoisier with his work on pathology. With his directness, Lavoisier informed Marat of his negative assessment of these works. In 1789, Marat became one of the most brutal leaders of the revolution and remembered ancient dinners. He persistently demanded in the Convention executions for Lavoisier - "the redeemer and the enemy of the people". The great chemist was on the guillotine. Undoubtedly, Vorobyev's "red arborist" was far away from Marat, but he fulfilled his black duty as a prosecution witness to the end, providing the investigation with the desired evidence of the suspected counter-revolutionary activity ${ }^{15}$.

As a result of several months of heavy interrogation, the prisoners were brought to self-denial (a legal term). They have almost all admitted the accusations made against them.

At a court hearing on June 14, 1930, Professor B. A. Shustov was found guilty of "jointly with a group of other employees of VUPL counter-revolutionary forestry specialists, mainly old figures of the forest department, aimed at disrupting the forest by directing capitalist forms, the perversion of practical measures in the forestry sector, a number of harmful actions in different areas of forestry, and the weakening of the economic power of the USSR" ${ }^{\text {"16. }}$.

The opinion of the Kyiv City Prosecutor's Office of December 20, 1991 stated: "The sentence is based on the self-refutation and condemnation of the sentenced employees of the Marchenko, Shustov, Gursky, Kovalenko and Padalka Forestry, and there is no objectively reliable evidence in the case. Testimony of witnesses Sadovsky, Vorobyov, Golovchenko, etc. do not contain information on the counter-revolutionary activities of the prisoners ${ }^{17}$.

15 Boreyko V. E. (2003) Belye pyatna prirodookhrany. p. 14.

${ }^{16}$ Obvinitel'noe zaklyuchenie po "Delu VUPL" [Indictment on VUPL Case]. OGA SB Ukrainy [BSA SS of Ukraine]. D. 68461. Vol. 2. Pp. 186-187. (unpublished)

17 Zaklyuchenie Prokuratury g. Kieva ot 20.12.1990 g. v otnoshenii Kolesnikova A. I. po materialam ugolovnogo dela [The conclusion of the Prosecutor's Office in Kiev dated 12/20/1990 in relation to A. Kolesnikov based on the materials of the criminal case]. OGA SB Ukrainy [BSA SS of Ukraine]. D. 68461. Vol. 2. P. 23. (unpublished) 
Although the investigation is not over yet, the forestry community is already raising its angry voice against the "pests". February 27, 1930, the board of the institute from angered students of the first year of the faculty of the organization of agriculture, land reclamation and forestry faculty received a characteristic requirement at that time "to release the scoundrel Levakovsky from the faculty of the institute" for the fact that he voted against the resolution, "which exposed the pests of social construction - former professors of lesfak" ".

The author of the devastating article in the fourth issue of Ukrainian Arborist in 1930, M. I. Romanovsky stated: "This counterrevolutionary group in forestry, using its position in responsible positions in the forestry, set itself the task of preserving the landlords first of all" L. Dashkevich in the article "For the proletarian cadres" in the same "Ukrainian Arborist" stated: "The matter of training forestry personnel is in the hands of a class alien to us professors" ${ }^{20}$. A resolution of the All-Ukrainian Union of Agricultural and Forestry Workers, published in the same journal, called for "the harshest punishment for a group of pests-specialists in agriculture and forestry" ${ }^{21}$. However, attacks on the forest fossils did not save the last surviving professional forest journal of Ukraine at the time: its management was accused of pestering a pest group, and the 1930s became the last year of issue of this print body. The decision of the future court did not cause any doubt.

18 Protokol obshchego sobraniya studentov KhSKhI [Protocol of the general meeting of students of the KhSKhI]. Derzhavnyj arkhiv Kharjkivsjkoji oblasti [The State Archive of Kharkiv Oblast]. f. R-1148. op. 7. d. 37. 1. 52. (unpublished)

${ }^{19}$ Romanivsjkyj I. (1930) Na borotjbu z kontr-revoljucijnym shkidnyctvom [To combat counter-revolutionary wreckage]. Ukrajinsjkyj lisovod [Ukrainian arborist]. № 4. P. 1 .

${ }^{20}$ Dashkevych L. (1930) Za proletarsjki kadry [For proletarian shots]. Ukrajinsjkyj lisovod [Ukrainian arborist]. № 10/12. P. 8.

21 Najsuvorishoji kary ghrupi shkidnykiv-specialistiv v siljsjkomu ta lisovomu ghospodarstvi Ukrajiny: postanova prezydiji VUKu SGhLR pro shkidnycjku orghanizacijeju v siljsjkomu ta lisovomu ghospodarstvi Ukrajiny (1930) [The harshest punishment for a group of pests-specialists in agriculture and forestry of Ukraine: the decision of the Presidium of VUK of the SGLR on a pest organization in agriculture and forestry of Ukraine]. Ukrajinsjkyj lisovod [Ukrainian arborist]. № 4. Pp. 5-6. 
In the late 1920's, beginning with the Soviet Union's industrialization, the need for business wood increased not only for domestic use but also for the purpose of obtaining currency to cover the cost of importing foreign equipment. Stalinist policy of "socialist assault" required the formation of organs of the forest this type of economy is of the economic-production type instead of the existing management one. The VUPL protected the forests from increased felling, determined logs for each year only in accordance with estimated estimates, and fined the industry for excess felling and failure to comply with clearing rules. On the basis of the resolution of the Ukrainian Economic Meeting of July 23, 1923, the only logger in Ukraine was approved by the All-Ukrainian Forest Management, which was to supply the already developed forest to industrial organizations $\mathrm{s}^{22}$. To eliminate foresters from logging, it was necessary to organize forest management on a "new basis".

On July 12, 1929, the Labor and Defense Council of the RSFSR adopted a decree "On the reorganization of the forestry and forest industry". Its preamble testified that the restructuring was carried out "with the aim of developing the timber industry, more fully meeting the needs of timber, maximizing forest exports, reducing the cost of production of timber industry and increasing the size of forestry profits". August 27, 1929 issued a resolution of the USSR Labor and Defense Council "On the prospective plan for the development of forestry and forest industry of the USSR for the five years 1928/1929 - 1932/1933". With its adoption, "Ukrainian forestry lost its independence and had to put to the fore the forest management task on the basis of lowered timber needs calculations" ${ }^{\prime 23}$.

On November 13, 1929, in accordance with the decision to reform the forest industry, instead of the abolished HPP in Ukraine, the management of Ukrderzhles was formed. Head of the Central Department of Forests of the People's Commissar of the USSR M. G. Zdoryk cynically stated: "As long as we need a forest, we will cut it down to the size of our need,

${ }^{22}$ Ivanycjkyj B. G. (1936) Lisy i lisove ghospodarstvo na Ukrajini [Forests and forestry in Ukraine]. T. 2. Varshava. P. 79.

${ }^{23}$ Ivanycjkyj B. G. (1936) Lisy i lisove ghospodarstvo na Ukrajini. P. 80. 


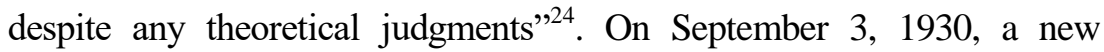
resolution was issued, "On the Organization of the Forest Industry and Forestry", by which Moscow selected forest funds of the Union republics solely on its own ${ }^{25}$.

There was a heated debate among foresters about the principles of forest management. The fundamental principles of sustainability, unacceptability of exhaustion and continuity of use of the forest, developed by the classic of forest science G. F. Morozov and laid down in the forest management instruction of the RSFSR in 1926 by his colleague M. M. Orlov were severely criticized. Based on this instruction, a similar instruction was drawn up in 1927 for Ukraine. This bacchanalia was called "the ideological struggle on the forest front". The result of this "discussion" was, in fact, the defeat of forest science, the arrests and repression of the entire leadership.

In Ukraine, during this period, forestry was merged with the logging bodies, and the state farms were formed, called to "carry out all production processes for logging, raising the productivity of forest stands and improving their quality, logging, primary processing and processing of wood" ${ }^{\prime 26}$. It was exactly what competent experts warned in 1923 - the interests of the forestry were fully subordinated to the interests of the forest industry. This, in particular, was reflected in the list of scientific topics on which the Ukrainian Research Institute of Forestry and Agroforestry worked during the first years of existence ${ }^{27}$. In connection with the reorganization during which the All-Ukrainian Forest Management was abolished, trade unions of forest workers and woodworkers were also united. In the autumn of 1930, the 1st United All-Ukrainian Congress of the Union of Forestry Workers and Forestry Workers (according to the terminology of the time), which outlined measures to "transfer the production experience of woodworking

${ }^{24}$ Red'ko G. I. (2002) Istoriya lesnogo khozyaystva v Rossii [History of forestry in Russia]. Moscow: MGUL. P. 393.

${ }^{25}$ Ivanycjkyj B. G. (1936) Lisy i lisove ghospodarstvo na Ukrajini. P. 81.

${ }^{26}$ Ghuba A. (1929) Na novi rejky [On new rails]. Ukrajinsjkyj lisovod [Ukrainian arborist]. № 12. P. 28.

27 Tkach V.P., Mjeshkova V. L. (ed.) (2005) UkrNDILGhA [UkrNDILGhA]. Kharkov: UkrNDILGhA. P. 12-14, 17. 
enterprises to the work of forestry". The congress also supported the decision of a special commission to clean the Central Committee ${ }^{28}$.

At the same time, a campaign on moral harassment, administrative and judicial prosecution of forestry experts and leading foresters of Ukraine was launched.

Lacking objective information about the harmful activities of the detainees, the GPU began to accumulate information during mass interrogations of forestry workers ${ }^{29}$. The technology of gathering accusatory evidence was mainly that in endless "interviews" investigators, through moral and physical pressure, forced the suspects and witnesses (because who and what the bench would have to determine in court) tell their own biographies in the smallest detail, describe all events occurring in the national forestry for the last $15-20$ years.

It was also necessary to characterize the activities of as many colleagues as possible. Then began the intensified inflating of professional differences between the individual defendants in the case, and the right was recognized by one whose position more fully met the needs of "socialist construction". All other options were considered hostile and harmful. For example, the witness the arrest of V. Gursky, who was arrested in the VUPL case, on his differences with the position of the VUPL on the issue of concentrated logging in the Ukrainian forests formed the basis of the trumped up investigation by the management of the management of the pest management of forest management ${ }^{30}$.

28 Barvish E. D. (1930) Pidsumky 1-gho Ob'jednanogho Vseukrajinsjkogho z'jizdu profspilky lisdrevrobitnykiv [Results of the 1st United All-Union Congress of the Forest Workers Union]. Ukrajinsjkyj lisovod [Ukrainian arborist]. № 10/12. Pp. 9-13.

${ }^{29}$ Protokol doprosa V. Y. Gurskogo ot 27.09.1929 g. [Protocol of interrogation of V. Y. Gursky on 09/27/1929]. OGA SB Ukrainy [BSA SS of Ukraine]. D. 68461. Vol. 1. P. 1. (unpublished)

30 Pokazaniya V. Y Gurskogo na doprosakh v sentyabre - noyabre $1929 \mathrm{~g}$. [Testimony of V. Y. Gursky during interrogations in September - November 1929]. OGA SB Ukrainy [BSA SS of Ukraine]. D. 68461. Vol. 1. Pp. 33-35. (unpublished) 
Another rule of this cruel game was this: each of the suspects had to give any of the real facts the most negative interpretation for themselves (to speak for themselves). How wild is such an acknowledgment of A. I. Kolesnikov: "When I got from the student's bench in the teaching environment of old times, I wanted to achieve a privileged social position, material well-being, which I had not had before, forgetting about the interests and needs of the workers from whom I came" 31 . According to the logic of the investigation, belonging to the ranks of the intelligentsia, and even the presence of a certain worldview in a person was already considered a pledge of criminal acts on her part. To master these rules and begin to implement them for the death of himself and his colleagues did not succeed all and not at once. At the first interrogations, they were arrested mostly for no fault of themselves or for others. And only later, withstanding the blackmail, provocations, physical pressure of the investigators, began to expose everyone and everything, without excluding themselves. Here is the testimony of B. A. Shustov of February 5, 1930: "What is useful to the Proletarian State in general and what to do in my area of specialty - I firmly knew and knew, but did not intentionally do it" ${ }^{\prime 32}$. When inventing evidence of his own wreckage was no longer enough fantasy, it was possible to be released, as A. I. Kolesnikov did: "I silently contributed a share of wreckage to this case",33.

As a result of consideration of the materials of the archival investigation, we can assume such a course of events. Interrogations of witnesses concerning the activities of the VUPL began as early as September 1929. The information they provided allowed the GPU

31 Svidetel'stva A. I. Kolesnikova na doprose ot 07.02.1930 g. [Testimonies of A. I. Kolesnikov during interrogation of 02/07/1930]. OGA SB Ukrainy [BSA SS of Ukraine]. D. 68461. vol. 2. p. 419. (unpublished)

32 Svidetel'stva B. A. Shustova na doprose ot 05.02.1930 g. [Testimonies of B. A. Shustov during interrogation of 02/05/1930]. OGA SB Ukrainy [BSA SS of Ukraine]. D. 68461. vol. 2. p. 391. (unpublished)

33 Stenograficheskiy otchet o zasedanii chrezvychaynoy sessii Verkhovnogo Suda USSR po delu o vreditel'stve v lesnom khozyaystve Ukrainy ot 14.06.1930 g. [Verbatim record of the meeting of the extraordinary session of the Supreme Court of the Ukrainian SSR on the case of wrecking in the forestry of Ukraine from 06/14/1930]. OGA SB Ukrainy [BSA SS of Ukraine]. D. 68461. vol. 3. p. 630. (unpublished) 
investigator to identify possible actors in the future litigation. Numerous testimonies obtained from ordinary forestry workers in the course of dozens of interrogations have led to accusations against reputable forest scientists and forest managers in Ukraine.

One of the first was arrested by the Head of the Department of Forestry and Timber Reclamation Department of the VUPL Valerian Gursky (November 16, 1929) and the Head of the Forest Management Department Ivan Kovalenko (December 18, 1929). These were the ones who later "beat out" the largest number of accusations (Gursky was summoned for interrogation 19 times, and Kovalenko - 25). Their written testimonies were so detailed and full of details that, on their basis, it was conceivable that it would be possible to draw up a concise account of the work of the VUPL for the entire period of its existence. Then there was the head of the Bureau of Economic Statistics of the VUPL, Boris Padalko. With the arrest, a new year began in 1930, for the head of the forest subdivision of the State Planning Committee of the USSR, Alexander Marchenko. On January 20, Boris Shustov, the head of the Forest Management Commission at the Forest Management Department of the VUPL, was hit in the cell, and eight days after that, the Deputy Chief of the VUPL, Alexander Kolesnikov, was at the camera.

The purpose of the investigation was to bring as many facts as possible to the detriment of the accused. It was only necessary to obtain from the detainees' recognition in political views other than the official, as all the years of ascetic work far removed from the policy of people from the rescue of Ukrainian forests, the development of forestry science and forestry turned into a total wicked pest. The process of forming the VUPL was presented as a criminal conspiracy by counterrevolutionaries led by emissaries from Moscow. In fact, the All-Ukrainian Forest Management was in fact presented as a subversive organization that served as a cover for counterrevolutionary activity.

And the fruitful work of experienced forestry professionals was proof of their affiliation with the counter-revolutionary organization.

And the more they carried out this work with more energy and perseverance, the more, by the logic of the investigation, the 
country was harmed. By manipulating the facts, the investigation managed to paint a horrific picture of wreckage in virtually all areas of the counter-revolutionaries. Among the activities of the "pests" were forestry and research, seed production, forest management (in terms of the indictment), forest export, training of "red" personnel for forestry management, activities of the forestry journalist, forest policy and planning.

At the same time, the facts presented in the testimonials were mostly true, which cannot be said about their interpretation. Therefore, in the archival investigative materials you can find interesting documents reflecting the problems of a number of forestry sectors of the time. Much previously unknown details can be found in the investigation protocols and biographies of forest science fossils. Valuable for researchers of archival sources in the history of forestry may also be specimens of the handwriting of the subjects, who mostly wrote their testimonies and each page bore its own signature.

\section{Professor Boris Shustov and the development of domestic forest taxation}

The closed court session without the participation of lawyers and witnesses took place on 14 June 1930. The wholehearted admission of his guilt or his refusal did not have a significant effect on the sentencing of the defendants [Indictment]. According to the sentence of the Supreme Court of the USSR, in accordance with Article 54-7 of the Criminal Code of the USSR, B. P. Padalka - the only defendant who pleaded guilty - received 4 years of imprisonment "in public places". I. S. Kovalenko and O. G. Marchenko were sentenced to 5 years. A. I. Kolesnikov and B. A. Shustov received 6 years each, although the court found their "sincere repentance" a mitigating circumstance. The least (3 years) was awarded to V. Y. Gursky, considering his "sincere repentance, old age and a comparatively minor role in counter-revolutionary pest activity",

${ }^{34}$ Prigovor suda po Delu VUPL [Sentence of the court on the case of VUPL]. OGA SB Ukrainy [BSA SS of Ukraine]. D. 68461. Vol. 2. P. 668. (unpublished) 
This case was perhaps the first in a series of similar cases that were pursued by foresters and foresters throughout the USSR. Frankly, for the purpose of the detailed campaign, he pointed out in the 10th issue of the Bolshevik magazine for the 1932 USSR Forest Industry Commissar S. S. Lobov: "The introduction of scientific principles into forestry practice would inevitably lead to the disruption of the tasks of the forest industry deployment, so on the consumption of forest science and all there Morozov and Orlov. No estimated logs. To cut down on need, despite the wisdom of forest scientists" 35 .

In the years that followed, the adherents of the classic forestry system were attacked by an avalanche of pseudoscientific publications by angry forestry "innovators". Following his drug addict M. Alexeychyk and B. Chagin in their work "Against reactionary theories on the forest front. Criticism of the teaching of prof. Morozov and Orlov and their followers" blamed well-known scientists and practitioners for insisting on the reactivity of the theory of sustainability and uniformity of forestry of M. M. Orlov and the Morozov principle of the stability of the plantations and the independence of the forest, emphasizing their anti-Soviet orientation ${ }^{36}$. Further, the aforementioned work contains a very strange invective: "The economic and political restoration of the landlord system in Russia is the content of a candid statement by the defiant defender of reactionary ideas G. F. Morozov (this is 12 years after the death of the aforementioned forestry classic!)" ${ }^{\prime 37}$.

Even the subtitle of the book is astonished by the modern reader: "The idealistic teaching of Prof. Sukachev on the typology of the forest and its critique", "Landlord-capitalist principle of sustainability and one-dimensional use of prof. Orlov and our Soviet forest industry". The authors' argumentation was "indisputable": "The Morozovsky

35 Furdychko O. I., Bondarenko V. D. (2000) Pershopostati ukrajinsjkogho lisivnyctva. P. 31-32.

36 Alekseychik N. (1932) Protiv reaktsionnykh teoriy na lesnom fronte. Kritika ucheniya prof. Morozova i Orlova i ikh posledovateley [Against reactionary theories on the forest front. Criticism of the teachings of prof. Morozov and Orlov and their followers]. Moscow: Goslestekhizdat. P. 153.

${ }^{37}$ Alekseychik N. (1932) Protiv reaktsionnykh teoriy na lesnom fronte. P. 154. 
doctrine of the forest as a whole is reactionary. It is in sharp contradiction with the socialist practice of our economy"38. Numerous court "theorists" of forestry, without sparing the forces, brought the base into practice the destruction of forest resources of the country.

What has been achieved through this process for those who shaped forest policy in the country of the victorious proletariat? First, they have demonstrated that neither scientific authority nor years of diligent work give professionals even the highest rank the right to their own opinion, and even more so the right to defend it freely. Secondly, that neither the human fate nor the fate of our forests is of any importance to revolutionary expediency. For years, "The forest is cutting down wood chips are flying!" has become the norm of life, an excuse for the cruelty and injustice in the life of Soviet society.

This lawsuit has caused irreparable harm to both the Ukrainian forestry and its best representatives, grossly detached from their inspired service to the cause of their lives. As a result of the repression of foresters, Ukrainian forests were deprived of their faithful defenders, and systematic and large-scale violation of forest management principles led to the destruction of the ecosystem of forest-steppe and steppe zones of agriculture.

Not only did political repression cripple the fate of individuals, hamper the development of national science, destroy the economy, but also for many years distorted the moral and intellectual atmosphere in the country.

In the work list of B. A. Shustov, who is also in the family archive and is happily preserved, contains the entry: "Arrested GPU 20.01.1930". The following entry tells us that in the period from 12.11.1931 to 18.04. In 1937, B. A. Shustov was a senior researcher at the Research Institute of Forestry and Agricultural Land Reclamation in Kharkov (the so-called "sharashki").

From 1937 he took the position of the head of the Department of Forest Taxation at the Bryansk Forestry Institute.

${ }^{38}$ Alekseychik N. (1932) Protiv reaktsionnykh teoriy na lesnom fronte. P. 44. 
During World War II, Shustov was in an evacuation, working at the Voronezh Forestry Institute, located in the village of Lubyany, Tatar ASSR. In the spring of 1944 he returned to Bryansk, the Bryansk Forestry Institute. He died in Bryansk on January 30, 1945. The tomb was not preserved; a park was destroyed at the site of the cemetery. In 1991 he was completely rehabilitated by the Security Service of Ukraine.

\section{CONCLUSIONS}

The development of domestic forest taxation in the first half of the $\mathrm{XX}$ century is connected with the name of B. A. Shustov. In this area Shustov is known for his research on the study of the growth of forest plantations and the compilation of mass tables. After a break of more than 50 years since the time of Vargas de Bedemar, the beginning of the XX century. marked by a revival of attention to research on the growth of plantations. In 1909, the first work of B. A. Shustov appeared on the course of growth of oak high-barrels in the Tula and Mogilev provinces. In 1914, materials were published on the course of growth of overgrown oak stands in southern Russia. These were the first significant scientific works in the agricultural literature in the course of oak growth. Experimental material for them was collected by Boris personally, making a number of trips during the period 1908-1914. Thus, to study the growth of overgrown oak they were laid 55 test areas in Voronezh, Kursk, Kharkov, Kiev and Podolsk provinces.

B. A. Shustov compiled experimental and mass tables of trunk volumes in seed and overgrown oak plantations. Previously, German tables were used. In 1912, together with M. M. Orlov, he compiled tables "Volume and bends of pine trunks", built on a large experimental material of 5400 model trees. They replaced the tables of 1886 and the tables of A. A. Kruedener.

In 1923-1931, Professor B. A. Shustov made mass and assortment tables for taxation of all forest species of Ukraine (pine, oak, ash, birch, alder, aspen and hornbeam). In 1926 Shustov studied the course of growth of pine plantations in Ukraine, as well as compiled experimental tables of volumes of trunks. 
In 1931, official mass tables of volumes of trunks for oak (planting material) by bonus classes (discharges), compiled by Shustov on the experience of all his previous research, were published.

Finally, in 1939, B. A. Shustov compiled assortment tables for pine and spruce (planting material) of the Bryansk Forest. Massive volume tables of trunks of different tree species, along with the experience and growth charts of overgrown oak plantations, were included in the forest management directories and greatly benefited the organization and planning of the forestry.

Since 1931, B. A. Shustov has paid much attention to the issues of logging. As early as 1908, he laid out forest care trial areas in the Tula province, and in 1914 he re-taxed them. Since 1933, there have been a number of original works by Shustov on the history and practice of felling in oak and hornbeam plantations, based on extensive experimental material.

It was B. A. Shustov who was one of the first in the USSR to develop the problems of felling. This is the main agricultural technique of growing forests. They grow for about 100 years, so to get as much wood as possible every 10 years, they cut down the trees - they cut down dry, unhealthy, weakened trees, as well as trees that prevent the growth of the most promising specimens. Knowing what and how much to cut is very important, because it depends on the end result. Shustov was an advocate of the active influence of foresters on the formation of plantations ${ }^{39}$.

The theory of forest taxation is also the work of Shustov in determining the volume of tree trunks using a new formula and to develop a method of taxation and determine the stock of plantations without felling trees (1932).

In total, B. A. Shustov prepared about 50 and published 40 works. Their distinguishing feature is the connection of theory with practice, absorbed by the desire of the scientist to provide substantial assistance

39 Kotov A. I., Pamfilov V. V. (1960) Pamyati professora B. A. Shustova (k 15-letiyu so dnya smerti) [In memory of Professor B. A. Shustov]. Trudy Bryanskogo tekhnologicheskogo instituta [Proceedings of the Bryansk Technological Institute]. Vol. IX. Pp. 346-348. 
to production, and this is one of its great merits. This is his desire to explain the compilation of various collections: auxiliary tables for taxation of the forest, auxiliary tables for calculations in the forestry and satellite taxis.

\section{SUMMARY}

The era in which Professor Boris Shustov had to live and work was characterized by great drama and controversy. This fact greatly complicates her historiographical study. The ideological pressure of the totalitarian state, on the one hand, deprived the researchers of the possibility of objective consideration of historical phenomena, and on the other - derived from the scientific circulation huge arrays of primary sources. As for published historiographical works, their political writers often deliberately omitted the most poignant and dramatic episodes of the events of the history and biographies of its protagonists and covered the phenomena quite one-sidedly. There was a strong underestimation of the role of the creative personality in the development of society, which gave rise to a lack of attention to the study of the life and activities of prominent representatives of national science, technology and art. Probably, these factors were the reason why the powerful figure of scientist and organizer of science, teacher and practitioner B. A. Shustov remained in the shadows. Meanwhile, the opportunity to look at historical processes through the lens of the biography of a particular person allows you to open up new research horizons. History becomes specific and personified, it acquires a human face.

The moral aspect of biographical research is important: paying tribute to the figures of past years, the society is demonstrating to the new generations the exemplars of ascetic service in the chosen cause and motivating the young in their life choices.

In the course of analyzing the facts of a biographical order, it is extremely important to constantly relate them to the events of macrohistory, to write them in a historical outline. This allows you to uncover many of the causal relationships that have caused this or that turn of fate. It is these methodological approaches that underpin the work devoted to the life and activities of Professor B. A. Shustov. 


\section{REFERENCES}

1. Vakuljuk P. G. (1994) Sprava VUPLu [The case of VUPL]. Kiev: [b. v.]. (in Ukrainian)

2. Vakuljuk P. G. (1998) Reabilitovani istorijeju [Rehabilitated by History]. Kiev: [b. v.]. (in Ukrainian)

3. Vakuljuk P. G. (2004) Lisivnyky - zhertvy totalitarnoji systemy [Foresters are victims of the totalitarian system]. Kiev: Ukrcentrkadrlis. (in Ukrainian)

4. Vakuljuk P. G. (2005) Lisnychyj - gholovnyj ghospodar lisu [Foresters are the chief forest manager]. Kiev: Ukrcentrokadrlis. (in Ukrainian)

5. Vakuljuk P. G. (2006) Lisovidnovlennja ta lisorozvedennja v Ukrajini [Reforestation and deforestation in Ukraine]. Kharkov: Prapor. (in Ukrainian)

6. Furdychko O. I., Bondarenko V. D. (2000) Pershopostati ukrajinsjkogho lisivnyctva. Narysy do lisovoji istoriji [The First Figures of Ukrainian Forestry. Essays on forest history]. Lviv: Bibljos. (in Ukrainian)

7. Boreyko V.E. (2003) Belye pyatna prirodookhrany [White spots of Nature Conservation]. Kiev: Logos. (in Russian)

8. Kasjjanov V. G. (1992) Ukrajinsjka intelighencija 1920-kh 1930-kh rokiv: socialjnyj portret ta istorychna dolja [Ukrainian Intelligence of the 1920s - 1930s: A Social Portrait and a Historical Destiny]. K.: Ghlobus. (in Ukrainian)

9. Delo VUPL. Otraslevoy gosudarstvennyy arkhiv Sluzhby bezopasnosti Ukrainy (OGA SB Ukrainy) [Case of VUPL. Branch State Archive of the Security Service of Ukraine (BSA SS of Ukraine)]. D. 68461. Vol. 1-3. (unpublished)

10. Protokol sudebnogo zasedaniya ot $14.06 .30 \mathrm{~g}$. [The record of the court hearing of June 14, 30]. OGA SB Ukrainy [BSA SS of Ukraine]. D. 68461. Vol. 2. P. 630. (unpublished)

11. Arkhivnyj fond Chernighivsjkoji dukhovnoji konsystoriji f. 679, op. 10, spr. 317, ark. 440 zv. [Archive Fund of the Chernigiv Spiritual Consistory. F. 679. Op. 10. Sp. 317, arch. $440 \mathrm{zv].} \mathrm{(unpublished)}$ 
12. Triputina N. P. (2011) Professor A. I. Kolesnikov: stranitsy zhizni $i$ deyatel'nosti [Professor A. I. Kolesnikov: pages of life and activity]. Kharkov: KhNAGKh. (in Russian)

13. Vakuljuk P. G. (2000) Narysy z istoriji lisiv Ukrajiny [Essays on Forest History Ukraine]. Fastiv: Polifast. (in Ukrainian)

14. Pyatnitskiy S. S. (1966) Istoricheskiy ocherk fakul'teta lesovodstva [History of the Faculty of Forestry]. 150 let Khar'kovskomu ordena Trudovogo krasnogo znameni sel'skokhozyaystvennomu institutu im. V. V. Dokuchaeva (1816-1966) [150 years of the Kharkov Order of the Red Banner of Labor Agricultural Institute. V. V. Dokuchaev (1816-1966)]. Pp. 87-104.

15. Obvinitel'noe zaklyuchenie po "Delu VUPL" [Indictment on VUPL Case]. OGA SB Ukrainy [BSA SS of Ukraine]. D. 68461. Vol. 2. Pp. 186-187. (unpublished)

16. Zaklyuchenie Prokuratury g. Kieva ot 20.12.1990 g. v otnoshenii Kolesnikova A. I. po materialam ugolovnogo dela [The conclusion of the Prosecutor's Office in Kiev dated 12/20/1990 in relation to A. Kolesnikov based on the materials of the criminal case]. OGA SB Ukrainy [BSA SS of Ukraine]. D. 68461. Vol. 2. P. 23. (unpublished)

17. Protokol obshchego sobraniya studentov KhSKhI [Protocol of the general meeting of students of the KhSKhI]. Derzhavnyj arkhiv Kharjkivsjkoji oblasti [The State Archive of Kharkiv Oblast]. F. R-1148. Op. 7. D. 37. L. 52. (unpublished)

18. Romanivsjkyj I. (1930) Na borotjbu z kontr-revoljucijnym shkidnyctvom [To combat counter-revolutionary wreckage]. Ukrajinsjkyj lisovod [Ukrainian arborist]. № 4. Pp. 1-4.

19. Dashkevych L. (1930) Za proletarsjki kadry [For the proletarian cadres]. Ukrajinsjkyj lisovod [Ukrainian arborist]. № 10/12. Pp. 8-9.

20. Najsuvorishoji kary ghrupi shkidnykiv-specialistiv v siljsjkomu ta lisovomu ghospodarstvi Ukrajiny: postanova prezydiji VUKu SGhLR pro shkidnycjku orghanizacijeju v siljsjkomu ta lisovomu ghospodarstvi Ukrajiny (1930) [The harshest punishment for a group of pests-specialists in agriculture and forestry of Ukraine: the decision of the Presidium of VUK of the SGLR on a pest organization 
in agriculture and forestry of Ukraine]. Ukrajinsjkyj lisovod [Ukrainian arborist]. № 4. Pp. 5-6.

21. Ivanycjkyj B. G. (1936) Lisy i lisove ghospodarstvo na Ukrajini [Forests and forestry in Ukraine]. T. 2. Varshava. (in Ukrainian)

22. Red'ko G. I. (2002) Istoriya lesnogo khozyaystva $v$ Rossii [History of forestry in Russia]. Moscow: MGUL. (in Russian)

23. Ghuba A. (1929) Na novi rejky [On new rails]. Ukrajinsjkyj lisovod [Ukrainian arborist]. № 12. Pp. 27-31.

24. Tkach V. P., Mjeshkova V. L. (ed.) (2005) UkrNDILGhA [UkrNDILGhA]. Kharkov: UkrNDILGhA. (in Ukrainian)

25. Barvish E. D. (1930) Pidsumky 1-gho Ob'jednanogho Vseukrajinsjkogho z'jizdu profspilky lisdrevrobitnykiv [Results of the 1st United All-Union Congress of the Forest Workers Union]. Ukrajinsjkyj lisovod [Ukrainian arborist]. № 10/12. Pp. 9-13.

26. Protokol doprosa V. Y. Gurskogo ot 27.09.1929 g. [Protocol of interrogation of V. Y. Gursky on 09/27/1929]. OGA SB Ukrainy [BSA SS of Ukraine]. D. 68461. Vol. 1. P. 1. (unpublished)

27. Pokazaniya V. Y. Gurskogo na doprosakh $v$ sentyabre noyabre $1929 \mathrm{~g}$. [Testimony of V. Y. Gursky during interrogations in September - November 1929]. OGA SB Ukrainy [BSA SS of Ukraine]. D. 68461. Vol. 1. Pp. 33-35, 37, 41. (unpublished)

28. Svidetel'stva A. I. Kolesnikova na doprose ot 07.02.1930 g. [Testimonies of A. I. Kolesnikov during interrogation of 02/07/1930]. OGA SB Ukrainy [BSA SS of Ukraine]. D. 68461. Vol. 2. P. 419. (unpublished)

29. Svidetel'stva B. A. Shustova na doprose ot 05.02.1930 g. [Testimonies of B. A. Shustov during interrogation of 02/05/1930]. OGA SB Ukrainy [BSA SS of Ukraine]. D. 68461. Vol. 2. P. 391. (unpublished)

30. Stenograficheskiy otchet o zasedanii chrezvychaynoy sessii Verkhovnogo Suda USSR po delu o vreditel'stve v lesnom khozyaystve Ukrainy ot 14.06.1930 g. [Verbatim record of the meeting of the extraordinary session of the Supreme Court of the Ukrainian SSR on the case of wrecking in the forestry of Ukraine from 06/14/1930]. OGA SB Ukrainy [BSA SS of Ukraine]. D. 68461. Vol. 3. P. 630. (unpublished) 
31. Prigovor suda po Delu VUPL [Sentence of the court on the case of VUPL]. OGA SB Ukrainy [BSA SS of Ukraine]. D. 68461. Vol. 2. P. 668. (unpublished)

32. Alekseychik N. (1932) Protiv reaktsionnykh teoriy na lesnom fronte. Kritika ucheniya prof. Morozova i Orlova i ikh posledovateley [Against reactionary theories on the forest front. Criticism of the teachings of prof. Morozov and Orlov and their followers]. Moscow: Goslestekhizdat. (in Russian)

33. Kotov A. I., Pamfilov V. V. (1960) Pamyati professora B. A. Shustova (k 15-letiyu so dnya smerti) [In memory of Professor B. A. Shustov]. Trudy Bryanskogo tekhnologicheskogo instituta [Proceedings of the Bryansk Technological Institute]. Vol. IX. Pp. 346-348.

\section{Information about the author: Yuliia Dobrolyubska,}

Doctor of Sciences in Philosophy, Professor, Head of the Department of World History and Methodology of Science, South Ukrainian National Pedagogical University named after K. D. Ushinsky 26, Staroportofrankovskaya str., Odessa, 65020, Ukraine ORCID ID: orcid.org/0000-0002-3564-854X 